\title{
Evaluation of cholinesterase inhibitory activity of six Indonesian Cassia species
}

\author{
Suciati SUCIATI 1, $2 *$ (D), Erlinda Rhohmatul LAILI ${ }^{1}$ (D), Debora POERWANTORO ${ }^{1}$ (D), \\ Anita Probo HAPSARI 1 (D), Lailatul Zakiyah GIFANDA ${ }^{1}$ (D), Karma RABGAY ${ }^{3}$ (D), \\ Wiwied EKASARI ${ }^{1}$ (D), Kornkanok INGKANINAN 1,3
}

1 Department of Pharmacognosy and Phytochemistry, Faculty of Pharmacy, Universitas Airlangga, Surabaya 60115, East Java, Indonesia.

2 Center for Natural Product Medicine Research and Development, Institute of Tropical Diseases, Universitas Airlangga, Surabaya 60115, East Java, Indonesia.

3 Bioscreening Unit, Department of Pharmaceutical Chemistry and Pharmacognosy, Faculty of Pharmaceutical Sciences and Center of Excellence for Innovation in Chemistry, Naresuan University, Phitsanulok, Thailand

* Corresponding Author. suciati@ff.unair.ac.id (S.); Tel. +62-31-593 3150.

Received: 18 December 2019 / Revised: 12 May 2020 / Accepted: 01 June 2020

ABSTRACT: Alzheimer's disease (AD) is a neurodegenerative disorder, which is the most common cause of dementia. The aging population means that the number of people suffering from AD is expected to increase each year if there is no effective treatment found. One of the strategies for the treatment of $\mathrm{AD}$ is the use of cholinesterase inhibitors. Plants have been the source of many bioactive metabolites, including cholinesterase inhibitors. The objective of this study is to investigate the potency of several plant extracts from the genus Cassia as cholinesterase inhibitors. The cholinesterase inhibitory screening was carried out against two enzymes, acetylcholinesterase (AChE) and butyrylcholinesterase (BChE), according to the modified Ellman's method. The chemistry of the active fractions was studied by LC-MS/MS method. The results suggested that amongst six plant extracts from the genus Cassia investigated, the ethanolic extract of Cassia spectabilis showed the strongest inhibition against both AChE and BChE enzymes, with $\mathrm{IC}_{50}$ values of 39.5 and $36.9 \mu \mathrm{g} / \mathrm{mL}$, respectively. Investigation on the $n$-hexane, ethyl acetate, and $n$ butanol fractions obtained from the $C$. spectabilis extract showed that the ethyl acetate and the $n$-butanol fractions gave better inhibitory activity compared to the $n$-hexane fraction. Based on the LC-MS/MS data, the two active fractions gave similar profile. Both fractions contained alkaloid cassine and spectaline, which may responsible for the cholinesterase inhibitory activity.

KEYWORDS: Cholinesterase inhibitor; Alzheimer's disease ; Cassia species; Cassia spectabilis.

\section{INTRODUCTION}

Alzheimer's disease (AD) is a progressive neurodegenerative disorder, which is the most common cause of dementia [1]. The manifestation of this disease includes irreversible memory and cognitive deficiency. The common feature of this disease is the low level of the neurotransmitter acetylcholine in the brain due to loss of cholinergic nerves as well as the presence of senile plaques and neurofibrillary tangles which can destroy the neurons [1,2]. This disease commonly occurs in elderly ages, and the onset mostly appears in the mid 60's population [1]. The increase in life expectancy means that the number of people suffering from $\mathrm{AD}$ is anticipated to increase each year if there is no effective treatment found.

As cholinergic deficiency is the common feature of $\mathrm{AD}$, one of the treatments for this disease is the use of acetylcholinesterase (AChE) inhibitor, such as tacrine, donepezil, rivastigmine, and galantamine. Tacrine and donepezil are both synthetic compounds, while rivastigmine is a derivative developed from natural compound physostigmine [3]. Galantamine is an AChE inhibitor derived from natural sources. It is an alkaloid which first isolated from the snowdrop Galanthus nivalis (Amaryllidaceae) [4]. Studies have shown that these compounds gave benefits on cognitive, functional and behavioral effects on AD patients, however, several side effects and limited effectiveness have also been reported $[5,6]$. Another natural product that has

How to cite this article: Suciati, Laili ER, Poerwantoro D, Hapsari AP, Gifanda LZ, Rabgay K, Ekasari W, Ingkaninan K. Evaluation of cholinesterase

inhibitory activity of six Indonesian Cassia species. J Res Pharm. 2020; 24(4): 472-478. 
been studied thoroughly as AChE inhibitor is a sesquiterpene alkaloid, Huperzine A, obtained from Huperzia spp. The product containing extract of Huperzia spp has been commercialized as a food supplement for memory support in China [2].

Considering the two AChE inhibitors above are natural origin, research on finding either new or more effective compounds has been a target of many researchers. Recently we have reported the potency of several marine sponges as acetylcholinesterase inhibitor [7]. In the present study investigation of Cassia spp as cholinesterase inhibitor was carried out. The genus Cassia in the family Caesalpiniaceae have been known as flowering plants which comprising of more than 500 species, and are distributed widely in the tropical and subtropical regions [8-10]. Cassia spp are usually grown as ornamental plants, but many of these plants have great economic importance as well as its utilization in traditional medicine. The leave and the bark of Cassia fistula have been used to treat blackwater fever as well as a laxative [8]. Other traditional usages of Cassia spp have also been documented, such as for gastrointestinal problems, skin diseases, cough, bronchitis and cardiac disorders [10,11]. Metabolites reported from Cassia species include anthraquinones, terpenoids, xanthones, flavonoids as well as alkaloids. Many of these compounds posses promising biological activities, such as antioxidant, anti-inflammatory, anticancer, antiplasmodial, and hepatoprotective agents [11-14]. Anti-AD activity was reported from Cassia obtusifolia; the seeds extract of this plant can improve memory and learning in mice [15], as well as ameliorates amyloid $\beta$-induced synaptic dysfunction through anti-inflammatory and Akt/GSK-3 $\beta$ pathways [16]. C. obtusifolia extract was also found to inhibit AChE, BChE, and BACE1 ( $\beta$-site amyloid precursor protein cleaving enzyme 1) [17]. It was suggested that the napthopyrone compounds may be responsible for these activities [18]. Freitosa et al. (2011) have reported that the extract of Cassia alata leaves has shown AChE inhibition [19]. Based on these reports, the potency of other Cassia species as cholinesterase inhibitors is worth to be investigated.

\section{RESULTS AND DISCUSSION}

\subsection{Cholinesterase inhibitory assay}

The ethanolic extracts were prepared from the leaves of six species of the genus Cassia, namely Cassia spectabilis L. (Syn. Senna spectabilis L.), Cassia javanica L., Cassia grandis L.f, Cassia moschata Kunth, Cassia fistula L., and Cassia siamea Lam.(Syn. Senna siamea (Lam.) H.S. Irwin \& Barneby. The samples were screened against acetylcholinesterase $(\mathrm{AChE})$ and butyrylcholinesterase $(\mathrm{BChE})$ enzymes at a concentration of 100 $\mu \mathrm{g} / \mathrm{mL}$. The results as can be seen in Figure 1 suggested that the highest inhibition against both enzymes was given by $C$. spectabilis and the lowest inhibition was shown by $C$. fistula extract. The inhibitory activity of C. spectabilis extract was higher against BChE $(85.2 \%)$ compared to that against AChE enzyme (53.8\%). The C. spectabilis extract was further partitioned with, $n$-hexane, ethyl acetate, and $n$-butanol, sequentially. Each of the fractions was then subjected to cholinesterase inhibitory assay against both AChE and BChE enzymes. The results presented in Figure 2 indicated that the ethyl acetate and the $n$-butanol fractions gave higher inhibition against both enzymes, which suggested that the active compounds are possibly semipolar to polar compounds.

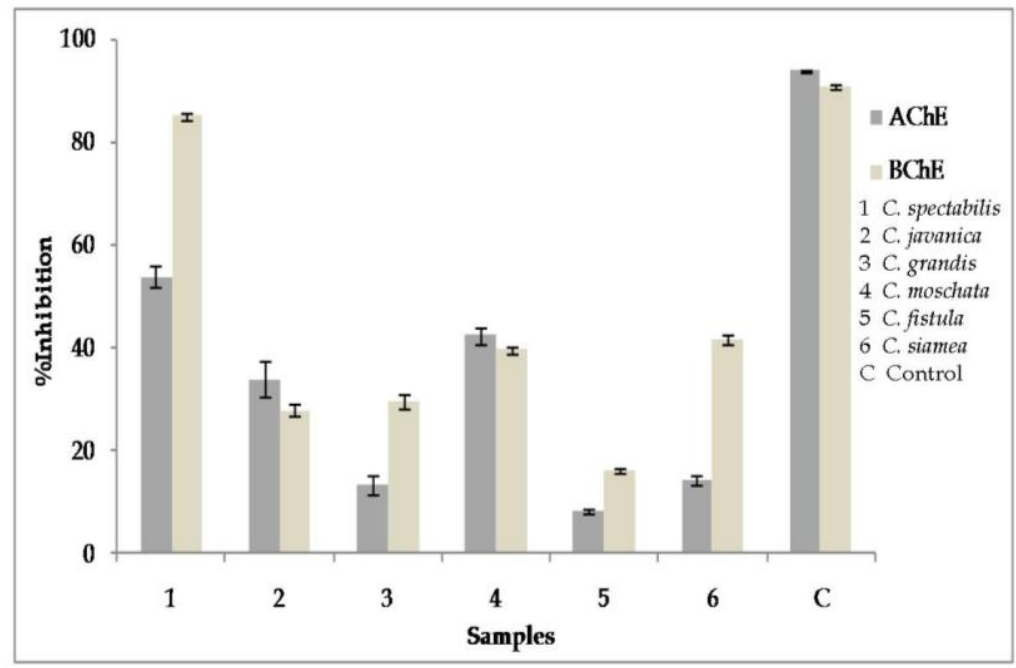

Figure 1. \%Inhibition of Cassia spp extracts and control (galantamine) against AChE and BchE. 


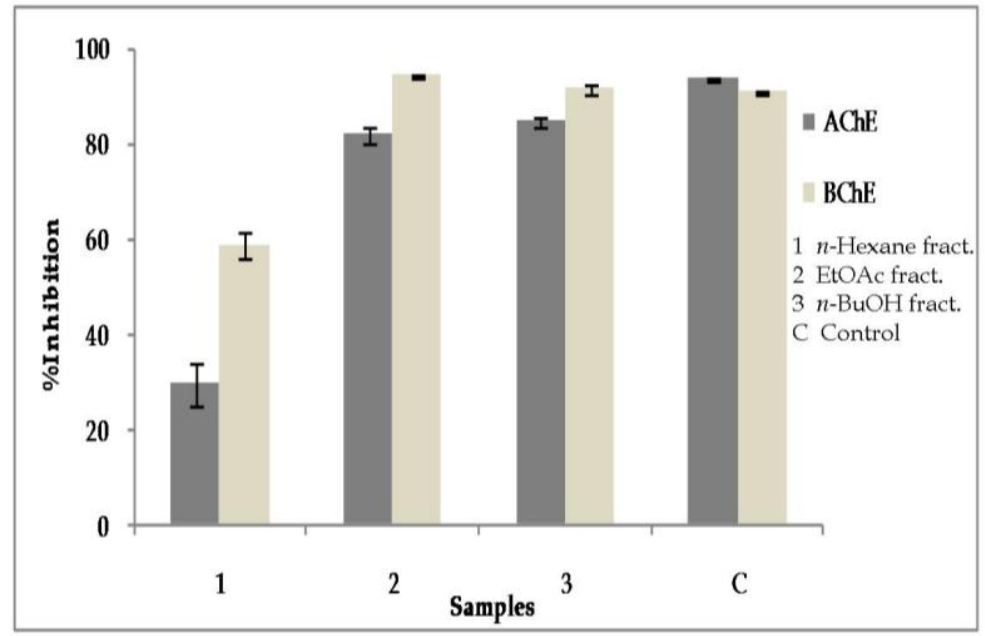

Figure 2. \%Inhibition of C. spectabilis fractions and control (galantamine) against AChE and BChE.

The $50 \%$ inhibitory activities of the ethanolic extract as well as the ethyl acetate and $n$-butanol fractions of $C$. spectabilis were also investigated. The results given in Table 1 show that all samples tested except galantamine exhibited lower $\mathrm{IC}_{50}$ values against $\mathrm{BChE}$ compare to $\mathrm{AChE}$. The lowest $\mathrm{IC}_{50}$ value was given by the ethyl acetate fraction of $C$. spectabilis at 10.8 and $4.7 \mu \mathrm{g} / \mathrm{mL}$ against $\mathrm{AChE}$ and $\mathrm{BChE}$, respectively.

Table 1. The $\mathrm{IC}_{50}$ C. spectabilis extract and fractions.

\begin{tabular}{lcc}
\hline \multirow{2}{*}{ Samples } & \multicolumn{2}{c}{$\mathrm{IC}_{50}(\mu \mathrm{g} / \mathrm{mL})^{\mathrm{a}}$} \\
\cline { 2 - 3 } & AChE & BChE \\
\hline Ethanol extract & $39.5 \pm 2.2$ & $36.9 \pm 5.1$ \\
Ethyl acetate fraction & $10.8 \pm 0.2$ & $4.7 \pm 0.1$ \\
$n$-Butanol fraction & $12.8 \pm 0.9$ & $10.2 \pm 0.9$ \\
Galantamine & $0.4 \pm 0.1$ & $2.2 \pm 0.3$ \\
\hline
\end{tabular}

a Data presented as mean \pm SD of three experiments, each done in triplicate.

The ethanolic extract of C. spectabilis was subjected to enzyme inhibiting kinetics study, and a Michaelis-Menten plot was determined (Figure 3). The Km value of the substrate ATCI (control) for AChE was $68.4 \mu \mathrm{M}$ and $V \max$ was $99.1 \mu \mathrm{M} / \mathrm{min}$. When the ethanolic extract of $C$. spectabilis leaves was added the $\mathrm{Km}$ and $V \max$ were $62.9 \mu \mathrm{M}$ and $74.7 \mu \mathrm{M} / \mathrm{min}$, respectively. There was no significant change in the $\mathrm{Km}$ values; indicated that the ethanolic extract of $C$. spectabilis inhibited AChE enzyme in a non-competitive way.

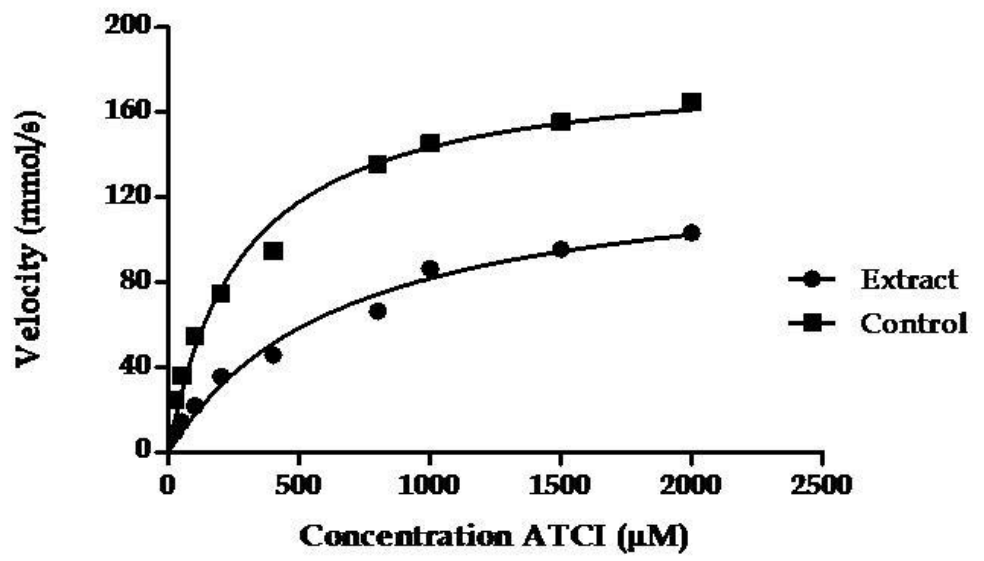

Figure 3. Michaelis-Menten plot of AChE inhibition of C. spectabilis extract. 


\subsection{Identification of metabolites by LC-MS/MS}

The chemistry of the ethyl acetate and the $n$-butanol fractions were studied by using LC-MS/MS instruments. The total ion chromatograms (TIC) of the two fractions were compared (Figure 4), which showed a similar TIC profile. Both fractions exhibited 2 major peaks at RT 2.57 (1) and 6.14 (2) mins, however, the ethyl acetate fraction also gave several minor peaks at RT approximately $6.9-17.9$ mins which was not seen in the $n$-butanol fraction. Based on the MS/MS data (Table 2) and comparison to the literature, the two major peaks were identified as cassine (1) and spectaline (2) (Figure 5) [20,21]. In the ethyl acetate fraction, a peak at RT 6.95 mins was observed, which was identified as 3-O-acetylspectaline (3). However, other minor peaks can not be identified unambiguously. Cassine and spectaline are two major piperidine alkaloids that have been reported from several parts of $C$. spectabilis, such as from the leaves and flowers [11, 22-24]. Piperidine alkaloids, such as iso-6-cassine and iso-6-spectaline, isolated from C. spectabilis have shown potency as depressant and anticonvulsant agents [25,26]. Viegas et al. (2005) and Castro et al. (2008) have developed semisynthetic derivatives from (-) spectaline isolated from the flower of $C$. spectabilis, the compounds exhibited inhibition against rat brain cholinesterase [27,28]. Freitas et al. (2018) have reported that the chloridrate form of cassine, spectaline, and 3-O-acetylspectaline demonstrated acetylcholinesterase inhibitory activity [21]. Based on the findings, it is possible that the cholinesterase inhibitory activity in the ethyl acetate and the $n$-butanol fractions of $C$. spectabilis corresponded to the presence of cassine, spectaline, and 3-O-acetylspectaline.

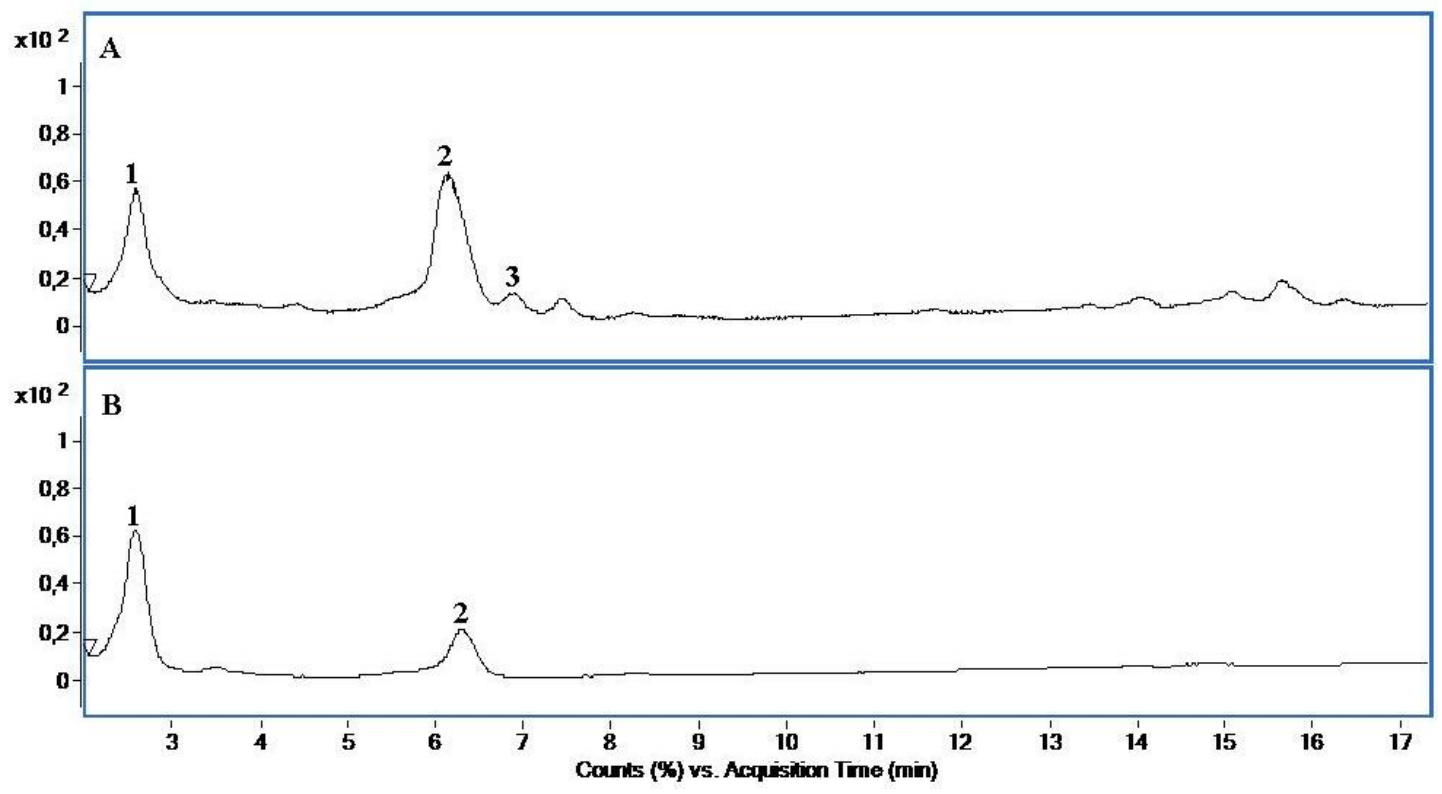

Figure 4. Total Ion Chromatograms (TIC) of the ethyl acetate (A) and n-butanol (B) fractions of C. spectabilis.

Table 2. LC-MS/MS data for identified alkaloids (1-3) from C. spectabilis extract.

\begin{tabular}{|c|c|c|c|c|c|c|}
\hline Compounds & RT (mins) & $\begin{array}{c}{[\mathrm{M}+\mathrm{H}]^{+}} \\
(\mathrm{m} / \mathrm{z})\end{array}$ & $\begin{array}{c}\text { Product ions } m / z \text { (relative } \\
\text { abundance) }\end{array}$ & Formula & $\begin{array}{l}\text { Exact } \\
\text { mass }\end{array}$ & $\begin{array}{c}\text { Mass error } \\
(\mathrm{ppm})\end{array}$ \\
\hline 1 & 2.62 & 298.2730 & $\begin{array}{c}280.2625(100), 210.1841(3.2) \\
198.1848(4.1), 123.1168(5.3) \\
109.1014(45.6)\end{array}$ & $\mathrm{C}_{18} \mathrm{H}_{35} \mathrm{NO}_{2}$ & 298.2741 & -3.69 \\
\hline 2 & 6.22 & 326.3050 & $\begin{array}{l}308.2931(100), 280.2631(4.7), \\
240.2335(1.0), 226.2181(3.6) \\
123.1165(5.4), 109.1012(21.8)\end{array}$ & $\mathrm{C}_{20} \mathrm{H}_{39} \mathrm{NO}_{2}$ & 326.3054 & -1.23 \\
\hline 3 & 6.95 & 368.3155 & $\begin{array}{l}308.2942(100), 280.2630(2.4), \\
240.2343(2.6), 226.2149(3.0) \\
123.1166(3.3), 109.1005(17.2)\end{array}$ & $\mathrm{C}_{22} \mathrm{H}_{41} \mathrm{NO}_{3}$ & 368.3159 & -1.09 \\
\hline
\end{tabular}

\footnotetext{
a Product ions at collision energy $40 \mathrm{eV}$
} 


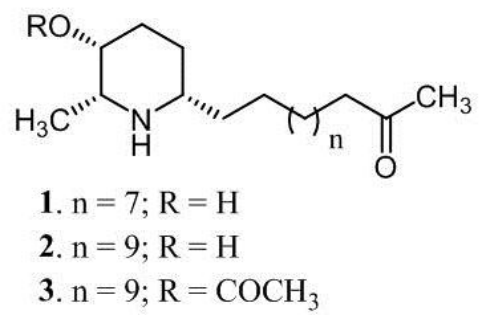

Figure 5. Structures of identified compounds (1-3) from C. spectabilis.

\section{CONCLUSION}

Based on these results, the ethanolic extract of Cassia spectabilis showed the strongest inhibition against both $\mathrm{AChE}$ and $\mathrm{BChE}$ enzymes amongst Cassia species tested. Further fractionation on C. spectabilis extract suggested that the ethyl acetate and the $n$-butanol fractions gave better inhibitory activities compared to the $n$-hexane fraction. Piperidine alkaloids, cassine, spectaline and 3-O-acetylspectaline which were identified in the active fractions, may contribute to the cholinesterase inhibitory activity of $C$. spectabilis.

\section{MATERIALS AND METHODS}

\subsection{Reagents}

Acetylcholinesterase from electric eel (AChE type VI-S), human recombinant acetylcholinesterase (hrAChE), horse-serum butyrylcholinesterase (BChE), acetylthiocholine iodide (ATCI), butyrylthiocholine iodide (BTCI), 5,5'-dithiobis[2-nitrobenzoic acid] (DTNB), and bovine serum albumin (BSA), tris buffer, and galantamine were obtained from Sigma-Aldrich.

\subsection{Plant collection, extraction and fractionation}

Plant materials were collected from Purwodadi Botanic Garden, East Java, Indonesia on March 9th, 2019. Sample specimens (Voucher numbers: PWD 01 - PWD 06) were kept at the Institute of Tropical Diseases Universitas Airlangga. The identification of plant materials was conducted by Purwodadi Botanic Garden (Identification letter number: 0371/IPH.06/HM/III/2019).

The leaves were air-dried for seven days at room temperature followed by grinding to obtain powdered materials. Ten grams of each samples were extracted with ethanol by using ultrasonic extraction for $3 \times 10$ mins, then the residue and filtrate were separated by filtration. The residue was re-extracted with ethanol using the same procedure for 3 times. The collected filtrate was then concentrated in vacuo to yield the crude ethanolic extracts $(0.5-2.0 \mathrm{~g})$. The ethanolic extract of $C$. spectabilis $(0.5 \mathrm{~g})$ was dissolved with a mixture of ethanol and $\mathrm{H}_{2} \mathrm{O}(1: 1)(20 \mathrm{~mL})$, then further separated by a liquid-liquid partition with $n$-hexane $(15 \mathrm{~mL})$, ethyl acetate $(15 \mathrm{~mL})$, and followed by $n$-butanol $(15 \mathrm{~mL})$. Fractionation with each solvent was conducted 3 times. Each of the fractions obtained was evaporated in vacuo, and yielded $n$-hexane $(46.9 \mathrm{mg})$, ethyl acetate $(184.4 \mathrm{mg})$, and $n$-butanol $(97.2 \mathrm{mg})$ fractions.

\subsection{Cholinesterase inhibitory assay}

The assay was carried out according to the modified Ellman's method [7,29-31]. Plant extracts were dissolved in methanol to make $10 \mathrm{mg} / \mathrm{mL}$ concentration, and was serially diluted with $50 \mathrm{mM}$ Tris buffer to obtain a $1 \mathrm{mg} / \mathrm{mL}$ concentration containing not more than $10 \%$ of methanol. These samples were further diluted in the microplate well to a final test concentration of $100 \mu \mathrm{g} / \mathrm{mL}$. Sample solutions were added to a 96-well microplate, followed by the addition of $1.5 \mathrm{mM}$ ATCI or $1.5 \mathrm{mM}$ BTCI $(25 \mu \mathrm{L}), 3 \mathrm{mM}$ DTNB $(125 \mu \mathrm{L})$, and Tris buffer $(50 \mu \mathrm{L})$. The substrate was then hydrolyzed by the addition of $25 \mu \mathrm{L}$ of $0.22 \mathrm{U} / \mathrm{mL}$ of either $\mathrm{Ee} \mathrm{AChE}, \mathrm{hr} \mathrm{AChE}$ or $\mathrm{BChE}$. The solutions were shaken for $30 \mathrm{~s}$ in a microplate reader (Bio-Tek Instrument, USA) before measurement. The product, 5-thio-2-nitrobenzoate, indicated by a yellow color was measured at $405 \mathrm{~nm}$ every $5 \mathrm{~s}$ for $2 \mathrm{~min}$. Every experiment was carried out in triplicates. Galantamine $(100 \mu \mathrm{L})$ was used as a positive control, and $10 \%$ methanol was used as a negative control. For the measurement of $\mathrm{IC}_{50}$, serial concentrations of the samples were prepared. The inhibitory activity was calculated as: \% Inhibition $=[($ Mean velocity of control - Mean velocity of sample $) /$ Mean velocity of control $] \times 100$. 


\subsection{Identification of Metabolites by LC-MS/MS}

Identification of metabolites was conducted by using Agilent 1260 Infinity Series HPLC system with an auto-sampler fitted with analytical C-18 column Agilent Poroshell 120 (Agilent Technologies, Santa, Clara, CA, USA). The HPLC was connected with an Agilent 6530 UHD Accurate-Mass Q-TOF LC/MS (Agilent Technologies), equipped with dual electrospray ionization (ESI). Samples were dissolved in methanol, and $10 \mu \mathrm{L}$ of samples were injected into the system employing gradient elution of $40-100 \%$ methanol $/ \mathrm{H}_{2} \mathrm{O}$ containing $0.1 \% \mathrm{v} / \mathrm{v}$ formic acid for $30 \mathrm{mins}$, flowrate $0.25 \mathrm{~mL} / \mathrm{min}$. $\mathrm{N}_{2}$ was employed as drying gas at a flowrate of $10 \mathrm{~L} / \mathrm{min}$. The temperature of the nebulizer was set at $325^{\circ} \mathrm{C}$, and the potential of the capillary was $3.5 \mathrm{kV}$. Positive mode was used and the scan mass range was 100-1000. The MS/MS collision energies were set at 10, 20, and $40 \mathrm{eV}$. The mass spectrometry data was analyzed using Agilent Mass Hunter Qualitative Analysis software version B06.00.

Acknowledgements: Authors acknowledge Faculty of Pharmacy, Universitas Airlangga for BOPTN research grant. Authors acknowledge the Ministry of Research, Technology, and Higher Education of the Republic of Indonesia for research grant PDUPT 2019. This work was also supported by the Thailand Research Fund [IRN61W0005], and the Center of Excellence for Innovation in Chemistry (PERCH-CIC), Ministry of Higher Education, Science, Research and Innovation, Thailand.

Author contributions: Concept - S.; Design - S., K.I.; Supervision -S. W.E., K.I.; Resources - S., K.I.; Materials - S., W.E., K.I.; Data Collection and/or Processing - E.R.L., D.P., A.P.H., L.Z.G., K.R.; Analysis and/or Interpretation - S., E.R.L., D.P., A.P.H., L.Z.G., K.R.; Literature Search - S., E.R.L., D.P., A.P.H., L.Z.G., K.R.; Writing - S.; Critical Reviews - S., E.R.L., D.P., A.P.H., L.Z.G., K.R., W.E., K.I.

Conflict of interest statement: The authors declared no conflict of interest

\section{REFERENCES}

[1] Bird TD. Genetic Aspects of Alzheimer Disease. Genet Med. 2008; 10(4): 231-239. [CrossRef]

[2] Murray AP, Faraoni MB, Castro MJ, Alza NP, Cavallaro V. Natural AChE Inhibitors from Plants and Their Contribution to Alzheimer's Disease Therapy. Curr Neuropharmacol. 2013; 11(4): 388-413. [CrossRef]

[3] Mathew M, Subramanian S. In Vitro Screening for Anti-cholinesterase and Antioxidant Activity of Methanolic Extracts of Ayurvedic Medicinal Plants Used for Cognitive Disorders. Plos one. 2014; 9(1): e86804. [CrossRef]

[4] Hostettmann K, Borloz A, Urbain A, Marston A. Natural Product Inhibitors of Acetylcholinesterase. Curr Org Chem. 2006; 10(8): 825-847. [CrossRef]

[5] Lleo A, Greenberg SM, Growdon JH. Current Pharmacotherapy for Alzheimer's Disease. Annu Rev Med. 2006; 57: 513-533. [CrossRef]

[6] Chopra K, Misra S, Kuhad A. Current Perspectives on Pharmacotherapy of Alzheimer's Disease. Expert Opin Pharmacother. 2011; 12(3): 335-350. [CrossRef]

[7] Suciati, Rabgay K, Fachrunniza Y, Saesong T, Hadi TA, Wahyuni TS, Widyawaruyanti A, Ingkaninan K. Enzyme Inhibitory Activities of Marine Sponges against Cholinesterase and 5a-Reductase. Malays Appl Biol. 2019; 48(3): 7783.

[8] Ganapaty S, Thomas PS, Ramana KV, Vidyadhar KN, Chakradhar V. A Review of Phytochemical Studies of Cassia Species. Journal of Natural Remedies. 2002; 2(2): 102-120.

[9] Dave H, Ledwani L. A Review on Anthraquinones Isolated from Cassia Species and Their Applications. Indian J Nat Prod Resour. 2012; 3(3): 291-319.

[10] Sundaramoorthy S, Gunasekaran S, Arunachalam S, Sathiavelu M. A Phytopharmacologucal Review on Cassia Species. J Pharm Sci Res. 2016; 8(5): 260-264.

[11] Jothy SL, Torey A, Darah I, Choong YS, Saravanan D, Chen Y, Latha LY, Deivanai S, Sasidharan S. Cassia spectabilis (DC) Irwin et Barn: A Promising Traditional Herb in Health Improvement. Molecules. 2012; 17(9): 10292-10305. [CrossRef]

[12] Torey A, Sasidharan S, Yeng C, Latha LY. Standardization of Cassia spectabilis with Respect to Authenticity, Assay and Chemical Constituents Analysis. Molecules. 2010; 15(5): 3411-3420. [CrossRef] 
[13] Deshpande HA, Bhalsing SR. Recent Advances in the Phytochemistry of Some medicinally important Cassia species: A Review. Int J Pharm Med Bio Sc. 2013; 2(3): 60-78.

[14] Ekasari W, Wahyuni TS, Arwaty H, Putri NT. Determination of Effective Dose of Antimalarial from Cassia spectabilis Leaf Ethanol Extract in Plasmodium berghei-Infected Mice. Aft J Infect Dis. 2018; 12(1 Suppl): 110-115.

[15] Kim DH, Yoon BH, Kim YW, Lee S, Shin BY, Jung JW, Kim HJ, Lee YS, Choi JS, Kim SY, Lee KT, Ryu JH. The Seed Extract of Cassia obtusifolia Ameliorates Learning and Memory Impairments Induced by Scopolamine or Transient Cerebral Hypoperfusion in Mice. J Pharmacol Sci. 2007; 105(1): 82-93. [CrossRef]

[16] Yi JH, Park HJ, Lee S, Jung JW, Kim BC, Lee YC, Ryu JH, Kim DH. Cassia obtusifolia Seed Ameliorates Amyloid $\beta$ Induced Synaptic Dysfunction through Anti-inflammatory and Akt/GSK-3 $\beta$ Pathways. J Ethnopharmacol. 2016; 178: 50-57. [CrossRef]

[17] Jung HA, Ali MY, Jung HJ, Jeong HO, Chung HY, Choi JS. Inhibitory Activities of Major Anthraquinones and Other Constituents from Cassia obtusifolia against $\beta$-Secretase and Cholinesterases. J Ethnopharmacol. 2016; 191: 152-160. [CrossRef]

[18] Shresta S, Seong SH, Paudel P, Jung HA, Choi JS. Structure Related Inhibition of Enzyme Systems in Cholinesterases and BACE1 In Vitro by Naturally Occuring Naphthopyrone and Its Glycosides Isolated from Cassia obtusifolia. Molecules. 2017; 23(1): 69-86. [CrossRef]

[19] Feitosa CM, Freitas RM, Luz NN, Bezerra MZ, Trevisan MT. Acetylcholinesterase Inhibition by Somes Promising Brazilian Medicinal Plants. Braz J Biol. 2011; 71(3): 783-789. [CrossRef]

[20] Pivatto M, Crotti AEM, Castro-Gamboa I, de Rezende A, Viegas C Jr, Young MCM, Furlan M, Bolzani VS. Electrospray Ionization Mass Spectrometry Screening of Piperidine Alkaloids from Senna spectabilis (Fabaceae) Extracts: Fast Identification of New Constituents and Co-metabolites. J Braz Chem Soc. 2005; 16(n-6b): 1431-1438. [CrossRef]

[21] Freitas TR, Danuello A, Viegas C Jr. Bolzani VS, Pivatto M. Mass Spectrometry for Characterization of Homologous Piperidine Alkaloids and Their Activity as Acetylcholinesterase Inhibitors. Rapid Commun Mass Spectrom. 2018; 32(15): 1303-1310. [CrossRef]

[22] Christofidis I, Welter A, Jadot J. Spectaline and Iso-6-cassine, Two New Piperidin 3-ol Alkaloids from The Leaves of Cassia spectabilis. Tetrahedron. 1977; 33(9): 977-979. [CrossRef]

[23] Viegas C Jr, Bolzani VS, Furlan M, Berreiro EJ, Young CM, Tomazela D, Eberlin MN. Further Bioactive Piperidine Alkaloids from the Flower and Green Fruits of Cassia spectabilis. J Nat Prod. 2004; 67(5): 908-910. [CrossRef]

[24] Pereira RM, Ferreira-Silva GÁ, Pivatto M, Santos LÁ, Bolzani VS, Chagas de Paula DA, Oliveira JC, Viegas C Jr, Ionta M. Alkaloids Derived from Flowers of Senna spectabilis, (-)-Cassine and (-)-Spectaline, Have Antiproliferative Activity on HepG2 Cells for Inducing Cell Cycle Arrest in G1/S Transition through ERK Inactivation and Downregulation of Cyclin D1 Expression. Toxicol in Vitro. 2016; 31: 86-92. [CrossRef]

[25] Silva FO, Silva MGV, Cerqueira GS, Sabino EB, Almeida AAC, Costa JP, Freitas RM. Iso-6-Spectaline Effects on Convulsions Induced in Epilepsy Models. J Young Pharm. 2011; 3(3): 232-236. [CrossRef]

[26] Silva FO, Silva MGV, Feng D, Freitas RM. Evaluation of Central Nervous System Effects of Iso-6-Cassine Isolated from Senna spectabilis var. excelsa (Schrad) in Mice. Fitoterapia. 2011; 82(2): 255-259. [CrossRef]

[27] Viegas C Jr, Bolzani VS, Pimentel LS, Castro NG, Cabral RF, Costa RS, Floyd C, Rocha MS, Young MC, Barreiro EJ, Fraga CA. New Selective Acetylcholinesterase Inhibitors Designed from Natural Piperidine Alkaloids. Bioorg Med Chem. 2005; 13(13): 4184-4190. [CrossRef]

[28] Castro NG, Costa RS, Pimentel LS, Danuello A, Romeiro NC, Viegas C Jr, Barreiro EJ, Fraga CA, Bolzani VS, Rocha MS. CNS-Selective Noncompetitive Cholinesterase Inhibitors Derived from The Natural Piperidine Alkaloid (-)Spectaline. Eur J Pharmacol. 2008; 580(3): 339-349. [CrossRef]

[29] Ellman GL, Courtney KD, Andres V Jr, Featherstone RM. A New and Rapid Colorimetric Determination of Acetylcholinesterase Activity. Biochem Pharmacol. 1961; 7(2): 88-95. [CrossRef]

[30] Ingkaninan K, Temkitthawon P, Chuenchom K, Yuyaem T, Thongnoi W. Screening for Acetylcholinesterase Inhibitory Activity in Plants Used in Thai Traditional Rejuvenating and Neurotonic Remedies. J Ethnopharmacol. 2003; 89(2-3): 261-264. [CrossRef]

[31] Sirimangkalakitti N, Olatunji OJ, Changwichit K, Saesong T, Chamni S, Chanvorachote P, Ingkaninan K, Plubrukarn A, Suwanborirux K. Bromotyrosine Alkaloids with Acetylcholinesterase Inhibitory Activity from the Thai Sponge Acanthodendrilla sp. Nat Prod Commun. 2015; 10(11): 1945-1949. [CrossRef] 